\title{
Anatomy, histochemistry, and comparative analysis of hydroxycinnamic derivatives in healthy leaves and galls induced by Baccharopelma spp. (Hemiptera: Psyllidae) in Baccharis spicata (Lam) Baill (Asteraceae)
}

\author{
Ignacio Agudelo ${ }^{a, *}$, Laura Cogoi ${ }^{b}$, Rosana Filip ${ }^{b}$, Nicolás Kuzmanich ${ }^{c}$, \\ Marcelo L. Wagner ${ }^{a}$, Rafael A. Ricco ${ }^{a}$ \\ a Cátedra de Farmacobotánica, Departamento de Farmacología, Facultad de Farmacia y Bioquímica, Universidad de Buenos Aires, Argentina

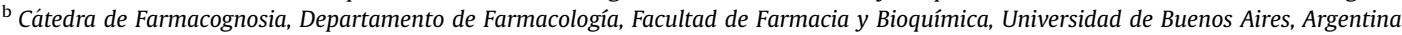 \\ c Instituto Multidisciplinario de Biología Vegetal-CONICET, Facultad de Ciencias Exactas, Físicas y Naturales, Universidad Nacional de Córdoba, Argentina
}

\section{A R T I C L E I N F O}

\section{Article history:}

Received 29 August 2017

Received in revised form

20 December 2017

Accepted 2 January 2018

\section{Keywords:}

Baccharis

Psyllidae

Insect induced galls

Histochemistry

Plant anatomy

\begin{abstract}
A B S T R A C T
Baccharis spicata is a plant native to the south of South America And is infected by psyllids of the Baccharopelma genus, which induce a fold gall in its leaves. This infection induces a series of anatomical and phytochemical variations compared to the healthy leaf: the content of total phenolic compounds and total hidroxycinnamic derivatives is lower, though the chlorogenic acid measured by HPLC remains the same and the 4,5 dichlorogenic acid content is near the half of the one observed in the one in the healthy leaf. Regarding to its anatomy, the gall has an homogeneous mesophyll and flavonoids in its outer epidermis compared to an isobilateral mesophyll and epidermal flavonoidic idioblasts observed in the leaf. The increase in the expression of waxes suggests it is a protective function against the desiccation by preventing water evaporation in the structure. The results here exposed suggest that the psyllid manipulates plant tissues, inducing hyperplasia and hypertrophy in the tissues, differentiating them from healthy structures and inducing changes in the biosynthesis of secondary polyphenolic metabolites that act like intermediary between the gall and the environment.
\end{abstract}

๑) 2018 Elsevier Ltd. All rights reserved.

\section{Introduction}

Baccharis is a genus of dioecious plants that belongs to the Asteraceae family with more than 400 species. It is native to the American continent, where it has medicinal representatives such as B.trimera and B.articulata (Cortadi et al., 1999). Baccharis spicata is a subshrub 1 and $1.5 \mathrm{~m}$ high, with opposite linear lanceolate leaves of $4-8 \mathrm{~cm}$ in length, a striated erect stem and capitula of $5-6 \mathrm{~mm}$ diameter arranging a false spike in its tips. It belongs to humid locations with few anthropogenic modifications in South Brazil, Paraguay, Uruguay, and the center of Argentina (Cabrera and Zardini, 1978).

B. spicata can be infected by psyllids from the Baccharopelma genus, which induce folding along the middle vein of the leaf and

\footnotetext{
* Corresponding author

E-mail address: iagudelo@ffyb.uba.ar (I. Agudelo).
}

generate a gall that belongs to the "fold" morphotype (Isaias et al., 2014b), green and $2-4 \mathrm{~cm}$ long.

Galls or cecidia are structures generated by a parasite on a plant (Shorthouse, 1992: Shorthouse et al., 2005; Isaias et al., 2014a), which causes an abnormal growth for its nourishment and the fulfillment of its life cycle. Galls induced by insects represent an extended phenotype since they are an expression of the host genes instead of the ones of the plant (Stone and Cook, 1998; Stone and Schönrogge, 2003; Raman, 2011), being able to differentiate species by the morphotypes induced.

The parasite produces a phenomenon of cellular hyperplasia and hypertrophy, which generates not only the above mentioned abnormal structure but also changes the production of secondary metabolites (Hartley and Lawton, 1992; Hartley, 1998; Stone and Schönrogge, 2003; Oliveira et al 2016). It has also been proved the capacity to alter the chemical defenses of the host (Tooker et al., 2008).

Polyphenolic compounds are important mediators in the biotic 
and abiotic interaction that plants have with their environment (Waterman and Mole, 1994), and have great importance in the relationship with phytophagous insects, where they have a defensive function (Matsuki, 1996; Simmonds, 2001, 2003). Inside this phytochemical group we can mention hydrolysable and condensed tannins, flavonoids, and hydroxycinnamic acids, derivatives of caffeic acid (Quideau et al., 2011).

These compounds have a defensive function, avoiding the infection of phytopathogenic and entomopathogenic fungi and repelling predators from the vegetal structure as from the insect host (Taper and Case, 1987; Ahn et al., 2005; Pascual-Alvarado et al., 2008). Besides they regulate the growth by inhibiting the indole acetic oxidase enzyme and increasing the average life of this phytohormone (Mapes and Davies, 2001; Bedetti et al., 2014).

The aim of this work is to characterize the anatomical, histochemical, and phytochemical variations between the gall and the healthy leaf, and its environmental importance.

\section{Materials and methods}

\subsection{Plant material}

Healthy leaves and galls specimens were analyzed from B. spicata collected from Reserva Ecologica Costanera Sur [Costanera Sur Ecological Reserve], city of Buenos Aires during the months of August and November 2016. All the specimens were found in the same phenological state. Insects as well as plants were identified as taxonomic keys (Burckhardt, 2008; Cabrera and Zardini, 1978). Of this population, 6 infected individuals and healthy individuals were employed for anatomical and phytochemical analysis.

Male and female specimens of reference can be found in the herbarium of Museo de Farmacobotánica "Juan Aníbal Domínguez" FFyB-UBA with number BAF IJA 002.

\subsection{Microscopic analysis}

\subsubsection{Cross section obtention}

The material was fixed with FAA and included in polyethylene glycol 6000 according to (Ferreira et al., 2014, 2017). The sections were obtained with a rotating microtome $(70 \mu \mathrm{m})$ using the technique described in (Argüeso, 1986). In both cases, safranin-fast green differential coloration was used, $30 \mathrm{~min}$ for the first coloring and $1 \mathrm{~min}$ for the second.

\subsubsection{Histochemistry of polyphenols}

It was performed with cross sections obtained with a rotating microtome of fresh material. They were incubated for $5 \mathrm{~min}$ with AEDBE $1 \%$ in methanol and they were analyzed with a fluorescence microscope Carl Zeiss Axioskop 2 Plus with a set of filter of 09 (BP 450-490; FT510, LP515). The color of the rutin fluorescence was determined applying $10 \mu \mathrm{L}$ of a solution of $1 \mathrm{mg} / \mathrm{ml}$ of each compound in filter paper as a standard.

\subsubsection{Scanning electron microscopy}

Samples were coated with gold-palladium and observed in an electron microscope Philips model XL30 TMP New Look.

\subsection{Phytochemical analysis}

\subsubsection{Total phenol quantification and Hydroxycinnamic derivatives}

These compounds were determined spectrophotometrically using methods and derivatives from hydroxycinnamic acid described in (Ricco et al., 2015) from extracts elaborated with $0.2 \mathrm{~g}$ of dry material in $10 \mathrm{ml}$ of methanol, macerated for $24 \mathrm{~h}$ and filtered with filter paper.

\subsubsection{Identification and quantification of compounds by HPLC}

The analysis of caffeoylquinic derivatives performed according to the methodology described by (Isolabella et al., 2010). All analysis were performed by triplicate.

\subsubsection{Chromatographic conditions}

A column C18 of $250 \mathrm{~mm}$ long with $4.60 \mathrm{~mm}$ of inner diameter and $5 \mu \mathrm{m}$ of particle size was used, Phenomenex ${ }^{\circledR}$, Luna (2).

The mobile phase consisted of mixing Solvent A (Water: Acetic Acid (98:2)) and Solvent B (Methanol: acetic acid (98:2)). Gradient: $15 \% \mathrm{~B}$ to $40 \% \mathrm{~B}$ in $30 \mathrm{~min}, 40 \% \mathrm{~B}$ to $75 \% \mathrm{~B}$ in $10 \mathrm{~min}, 75 \% \mathrm{~B}$ to $85 \% \mathrm{~B}$ in $5 \mathrm{~min}$, and $85 \% \mathrm{~B}$ to $100 \% \mathrm{~B}$ in $5 \mathrm{~min}$. Flow: $1.2 \mathrm{ml} / \mathrm{min}$. Detection wavelength was $325 \mathrm{~mm}$.

\subsubsection{Reference compounds}

5-caffeoylquinic acid (5-CQA, Sigma Aldrich, > 95\%) and cynarin (1,3-dicaffeoylquinic acid, ExtraSynthese, > 99\%) were employed in a concentration of $1.5 \mathrm{mg} / \mathrm{ml}$ of methanol each one a methanolic extract of yerba mate leaves (Ilex paraguarensis A. St. Hil) was used as a surrogate standard for the identification of 3,4-dicaffeoylquinic acid (3,4-diCQA), 4,5-dicaffeoylquinic acid (4,5-diCQA) and 3,5dicaffeoylquinic acid (3,5-diCQA), as reported in (Filip et al., 2001). The use of surrogate standards was suggested by previous authors for the identification of caffeoylquinic acids among other compounds (Clifford and Madala, 2017).

\subsection{Sample solvents}

\subsubsection{Caffeoylquinic acid quantification}

$0.5 \mathrm{ml}$ of each extract were diluted in $10 \mathrm{ml}$ of methanol for the quantification of 5-caffeoylquinic acid, and $1 \mathrm{ml}$ of each extract were diluted in $10 \mathrm{ml}$ of the same solvent for the quantification of 4,5-CQA; these compound was quantified as $\mathrm{mg}$ of cynarin equivalents.

\subsection{Statistical analysis}

Data was expressed as mean \pm standard deviation. Significative differences were considered with $\mathrm{p}<.05$. The program Graph Pad Prism $^{\circledR}$ was used.

\section{Results}

In the spectrophotometric quantitative analysis, the concentration of total phenols and hydroxycinnamic acids show an increase in the extracts derived from leaves compared to galls (Table 1). In spite of its inespecificity, the method used for the analysis of total phenols gives an overview of these metabolites for the comparison between the healthy leaf and the galls. The total hydroxycinnamic acid analysis is not specific for this family of metabolites since many substances have an absorption peak in

\section{Table 1}

Polyphenolic compounds content.

\begin{tabular}{|c|c|c|c|c|}
\hline & \multicolumn{2}{|c|}{$\begin{array}{l}\text { Total phenolic } \\
\text { compounds } \\
\text { (mg gallic acid/g dry } \\
\text { material) }\end{array}$} & \multicolumn{2}{|c|}{$\begin{array}{l}\text { Total } \\
\text { hydroxycinnamic } \\
\text { derivatives } \\
\text { (mg 5-CQA/g dry } \\
\text { material) }\end{array}$} \\
\hline & Average & SD & Average & SD \\
\hline Galls & 41.7 & 1.2 & 19.1 & 0.6 \\
\hline Healthy leaves & 124.0 & 8.31 & 49.3 & 1.4 \\
\hline
\end{tabular}


$325 \mathrm{~nm}$, which was the wavelength employed for this assay. However, previous research of our group (Agudelo et al., 2016) have shown that, in B. spicata leaves, the hydroxycinnamic derivatives are the predominant polyphenolic compounds. For this particular species, we can assume that this assay can be employed for a preliminar comparison.

Due to the abundance of caffeoylquinic derivatives observed in previous research above cited, these compounds were analyzed by HPLC (Table 2). 5-CQA acid concentration between galls and leaves did not had a significative difference $(\mathrm{p}<.05)$, although a difference in the concentration of 4,5-diCQA was detected. The concentration of this compound was reduced to half in the galls. Chromatograms can be seen in Figs. 1-5. 4,5-diCQA was the only dicaffeoylquinic acid detected by overlapping the chromatograms of $B$. spicata extract and the surrogate standard of I. paraguarensis.

The gravimetric analysis of the content of epicuticular waxes can be seen in Table 3. The average of epicuticular waxes found in galls doubled those of healthy leaves.

Regarding to microscopical analysis, the observation of the sections allows to establish differences between the healthy leaf and the gall. The healthy leaf presents uniseriate epidermis, isobilateral mesophyll of 2-3 of cell layers of palisade parenchyma and 2-3 layers of spongy parenchyma cells (Fig. 6). These results confirm the reports of previous investigations (Barboza, 2001). A parenchymatous sheath surrounds the central vascular bundle with a fiber cap on its adaxial and abaxial sides. The central vascular bundle presents cambium-like cells (Fig. 7). The gall presents an epidermis on its internal (Fig. 8) and external (Fig. 9) faces, a hypodermis 2-3 cells width and an homogeneous parenchyma with hyperplasia and hypertrophy of $12-15$ cells width (Fig. 10). The central vascular bundle of the gall has fewer fiber content compared to the healthy leaf and its parenchymatous sheath is smaller, though its phloem cells present content stained with safranin (Fig. 1) (see Fig. 11).

Polyphenol histochemistry show intense fluorescence in the leaf, of green color with isolated orange regions (Fig. 12). The phloem and the fiber caps present green fluorescence (Fig. 13). The gall fluorescesces only in the epidermis (Fig. 14), orange in the external face and green in the internal face. Tests of rutin fluorescence and 5-CQA were performed as standards for flavonoids and caffeoylquinic derivatives respectively; the first substance fluoresced orange, and the second shined green, although with the wavelength of excitement and absorption used, this fluorescence is barely distinguishable from the self-fluorescence of the tissues.

The study of the surface with scanning electronic microscopy shows the arrangement of the epicuticular waxes. In the healthy leaf, epidermic cells with striated cuticle and anomocytic stomata at level and in both surfaces, and flagelliform hairs with multicellular base can be seen (Fig. 15). In the galls, a great amount of epicuticular waxes deposits of ridges in the outer face (Figs. 16 and 17) and fissured layers and platelets in the inner face (Figs. 18 and 19) can be observed (Barthlott et al., 1998) which do not allow the visualization of epidermic cells.

Table 2

5-CQA and 4,5-diCQA content by HPLC.

\begin{tabular}{llllll}
\hline & $\begin{array}{l}\text { 5-caffeoylquinic acid } \\
\text { (mg 5-CQA/g dry } \\
\text { material) }\end{array}$ & & \multicolumn{2}{l}{$\begin{array}{l}\text { 4,5-dicaffeoylquinic } \\
\text { acid content (mg } \\
\text { cynarin equivalents/g } \\
\text { dry material) }\end{array}$} \\
\cline { 2 - 3 } \cline { 5 - 6 } & Average & SD & & Average & SD \\
\hline Healthy leaves & 0.53 & 0.03 & & 4.56 & 0.02 \\
Galls & 0.53 & 0.01 & & 2.48 & 0.02 \\
\hline
\end{tabular}

\section{Discussion}

When performing a quali-quantitative analysis between the gall and the healthy leaf, there is evidence that the gall shows a concentration of phenols and total hydroxycinnamic acids compared to the healthy leaf. Polyphenol compounds are known for their toxicity in insects, and their decrease suggests a lower defence against the feeding action of the inductor. Psyllids feed on savia by stinging this tissue with their stylet and the polyphenol compounds could affect the nutritional quality of the plant. These results are similar to the ones found by our group in the infection of Schinus longifolius by the Calophya mammifex (Agudelo et al., 2013). The studied polyphenolic compounds were selected according to a previous research conducted by our team (Agudelo et al., 2016).

It could be hypothesized that the reduction of polyphenolic compounds in the gall regarding the healthy leaf may be due to a decrease in the expression or an inhibition of phenylalanineammonia lyase enzyme to drive the plant's metabolism into the synthesis of aminoacids at the expense of the synthesis of polyphenols; however, when analysing the specific compounds, the concentration of 5-CQA does not remain altered when comparing the gall with the healthy leaf, though the concentration of 4,5diCQA is reduced by half. Inhibiting the PAL would reduce the 5CQA, which would lead to a decrease of all its derivatives; a possible explanation could be that the hydroxycinnamoylcoenzyme A quinate transferase is affected by the action of the insect. As described in previous works (Moglia et al., 2014), this enzyme catalyses the synthesis of 3,5-diCQA from 5-CQA; isomers 4,5 and 3,4 are synthetized by acyl group migration. This enzyme has different activities depending on its subcellular location: in the vacuole of plant cells, at $\mathrm{pH} 4$ it has the chlorogenic:chlorogenate transferase activity aforementioned, while the cytoplasm has a BAHD acyltransferase activity. Further research is necessary to know the subcellular location of this protein in healthy and infected organs.

Previous studies in the Baccharis genus have reported the presence of 3,5-diCQA, 3,4-diCQA, 4,5-diCQA and 3,4,5tricaffeoylquinic acid in B. trimera (Aboy et al., 2012; Simões-Pires et al., 2005), B. uncinella (Grecco et al., 2010), and B. genistelloides (Marques and Farah, 2009). Our results show that only 4,5-diCQA is present in B. spicata; for some reason 3,4-diCQA and 3,5-diCQA were not synthetized. A similar situation was reported in Pterocaulon virgatum (Asteraceae) (Martino et al., 1979); this species has only the 4,5-diCQA isomer, though in the bibliography its initial report was with non-IUPAC nomenclature as 3,4-diCQA. Previous articles have employed this species for the obtention of 4,5-diCQA (Filip and Ferraro, 2003). It would be interesting to repeat this analysis in individuals grown in different places and in different seasons, since our previous research has found that $B$. spicata grown in another location had the 3 di-CQA isomers (Agudelo et al., 2016).

Results of the anatomical study of the healthy leaf are in concordance with previous works (Barboza, 2001); the gall shows tissue hyperplasia and hypertrophy, with marked distinction in the mesophyll, which loses isobilateral structure and becomes homogeneous. The distinction suggests a decrease of the photosynthetic function and a protective thickening of the gall to shield the insect from the action of specialist parasitoids. The decrease of the photosynthetic function is a common feature among psyllidinduced galls (Patankar et al., 2011; Carneiro et al., 2014), as for their feeding way they act like a sewer of photo-assimilates without inducing the formation of nutritive tissue for feeding, though exceptions may be found (Oliveira et al., 2011).

The gall shows great amount of waxes, with deposits of fissured layers and platelets in the inner face and ridges in the outer face (Barthlott et al., 1998). This asymmetry between internal and 


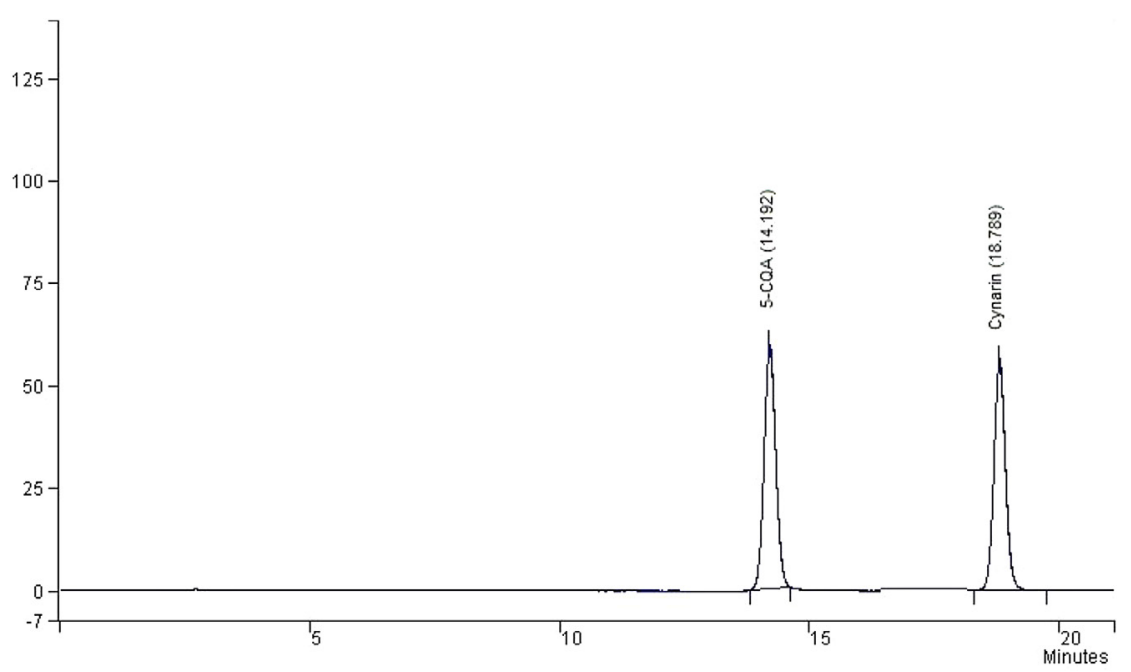

Fig. 1. 5-CQA and cynarin standard chromatogram.

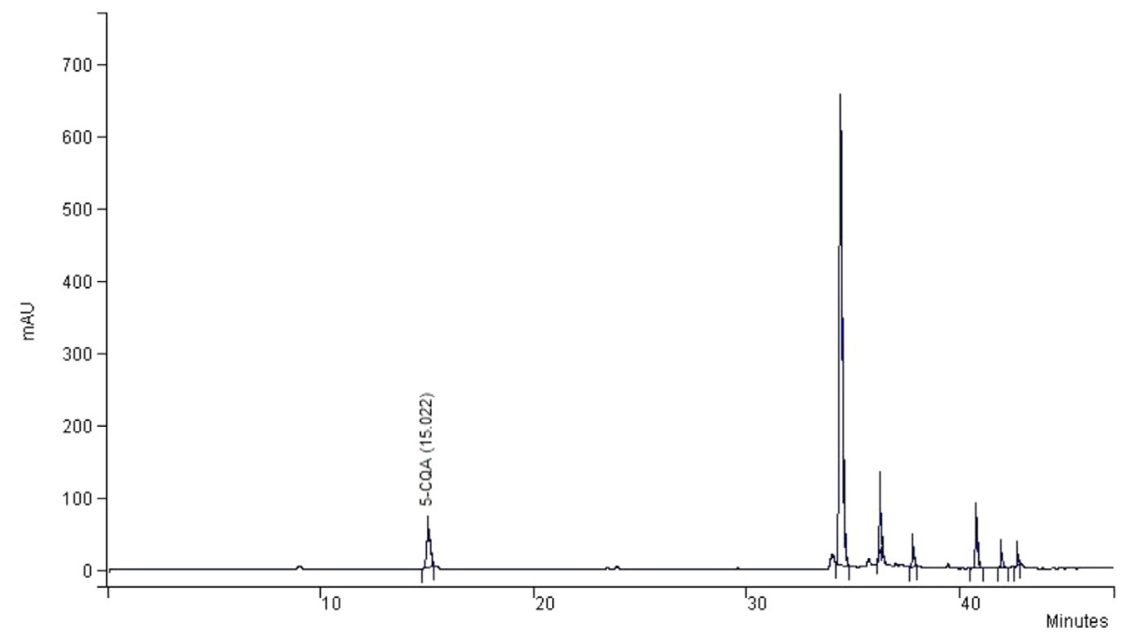

Fig. 2. 5-CQA chromatogram in leaves.

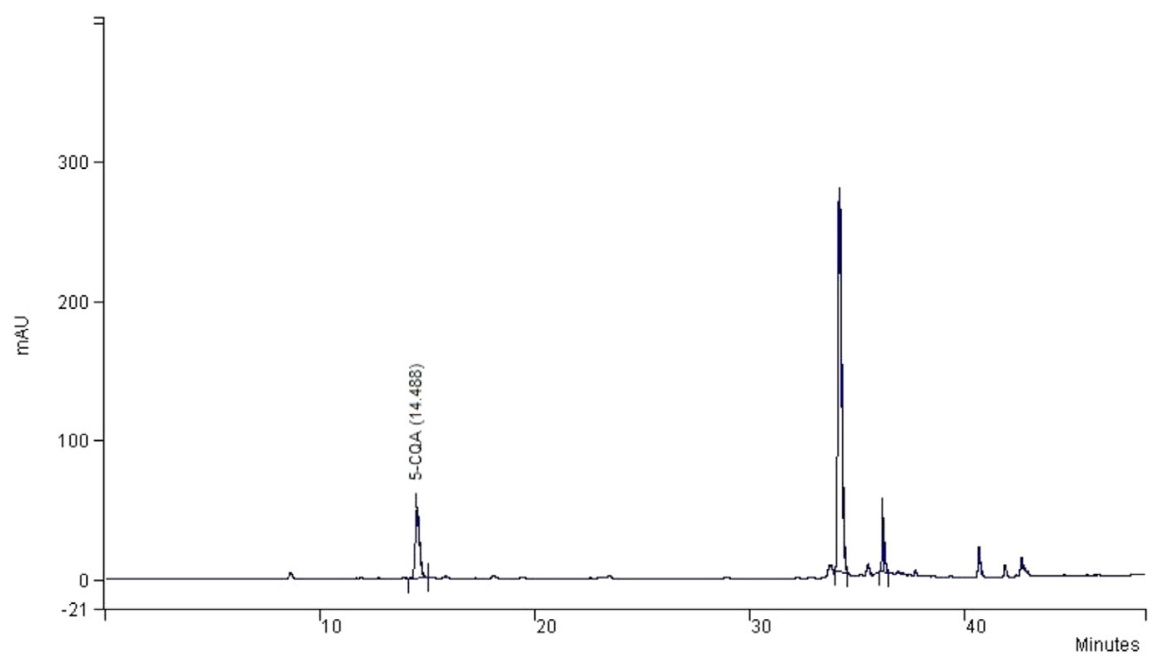

Fig. 3. 5-CQA chromatogram in galls. 


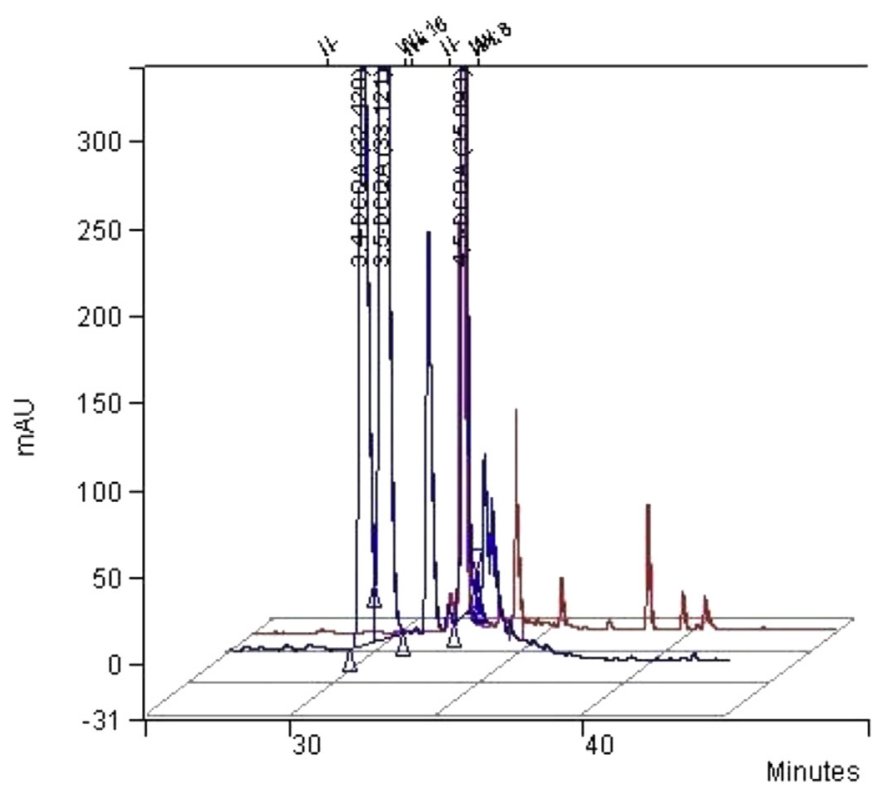

Fig. 4. Di-CQA chromatogram in leaves (overlap with I. paraguarensis extract).

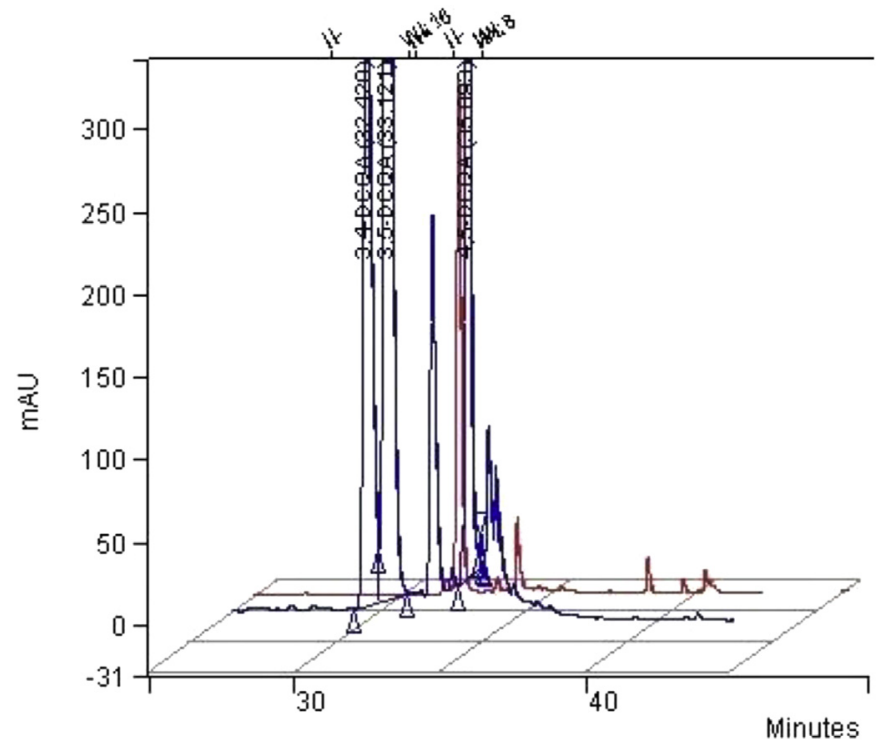

Fig. 5. DiCQA chromatogram in galls (overlap with I. paraguarensis extract).

Table 3

Epicuticular waxes content in galls and healthy leaves.

\begin{tabular}{lll}
\hline & Epicuticular waxes content & SD \\
\hline Healthy leaves & $4.53 \%$ & $0.5 \%$ \\
Galls & $11.35 \%$ & $1.1 \%$ \\
\hline
\end{tabular}

external epidermis is prominent in the differential expression of flavonoids in the outer layer. As these compounds are known as ultraviolet $B$ radiation blockers (UVB) and antioxidants, their expression increases under stress conditions with this physical agent, mainly of dihydroxy derivatives, with a larger amount of antioxidant activity than in monohydroxy derivatives (Ryan et al., 2002; Halbwirth, 2010). A complex phytochemical research

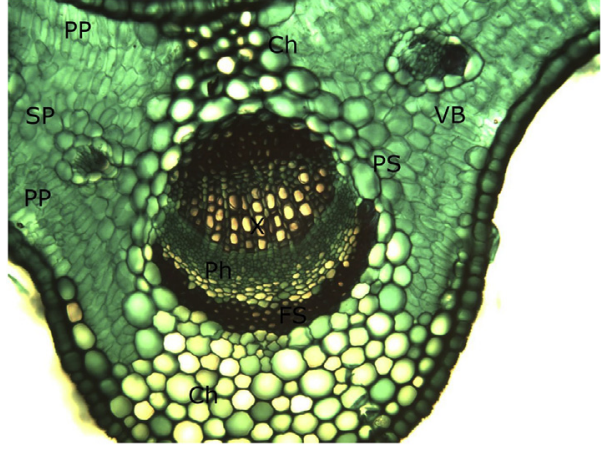

Fig. 6. Vascular bundle in healthy leaf.

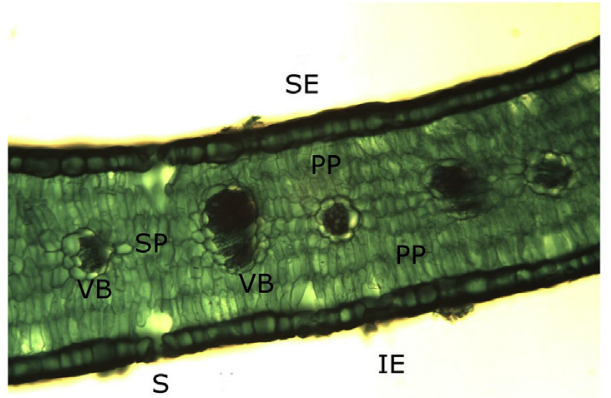

Fig. 7. Healthy leaf mesophyll.

Abbreviations: SE: Superior (Adaxial) Epidermis; IE: Inferior (Abaxial) Epidermis; S: Stomata; Ch: Collenchyma; FS: Fiber Sheat; Ph: Phloem; X: Xilema; VB: Vascular bundle; PS: Parenchymatous sheath; SP: Spongy Parenchyma; PP: Palisade Parenchyma.

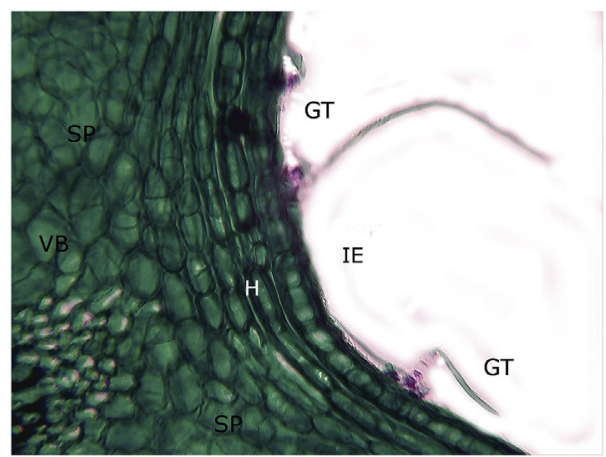

Fig. 8. Internal epidermis

would be required to reveal the identity of the compounds present in both sides of the epidermis and the mesophyll, as compounds present in the mesophyll may not have a role in the interaction with the environment.

According to the gravimetrical analysis, galls double the amount of epicuticular waxes of healthy leaves. These are known for their waterproof epidermis, preventing water evaporation and forcing stomata to regulate transpiration. Other roles are attributed to them like the production of auto-cleaning surface and a barrier against pathogens and UV-B radiation (Yeats and Rose, 2013). Though none of these roles can be ruled out, the differential expression of flavonoids suggests the protection against pathogens 


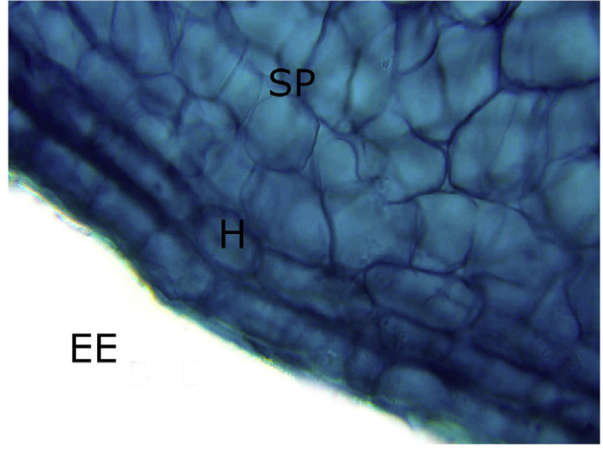

Fig. 9. External epidermis.

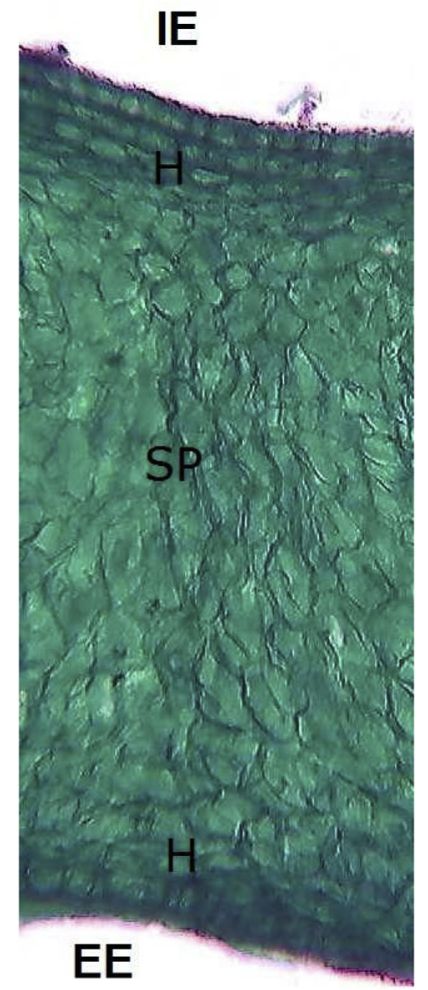

Fig. 10. Gall mesophyll.

and UV-B radiation would be important to secure the subsistence of the insects and support the plant structure. Fluorescence microscope images sustain this hypothesis, suggesting there is an interaction between the gall and the environment that is different from the one of the healthy leaf.

Tough other authors point out the differential expression of polyphenolic compounds in different gall tissue, most bibliography refers to wasps from Cynipidae and Tenthredinidae families, with galls and tissues significantly different from those produced by psyllids (Cornell, 1983; Harper et al., 2004; Nyman et al., 2000; Nyman and Julkunen-Tiitto, 2000).

The interaction between Baccharis dracunculifolia and Baccharopelma dracunculifoliae has been widely studied in the last years (Fernandes et al., 2014; Arduin et al., 2005; Besten et al., 2014; Magalhães et al., 2013). Morphologically, galls are very similar, but there are some anatomical differences. The main one is the

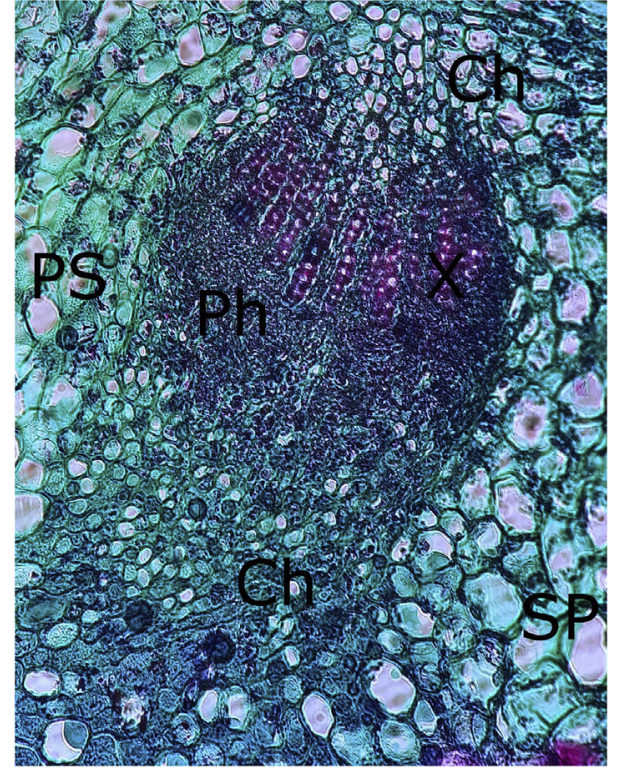

Fig. 11. Vascular Beam of the Gall.

EE: External Epidermis; IE: Inferior Epidermis; S: Stoma; H: Hypodermis; Ch: Collenchyma; FS: Fiber Sheat; Ph: Phloem; X: Xilema; VB: Vascular Beam; PS: Parenchymatous sheath; SP: Spongy Parenchyma; PP: Palisade Parenchyma.

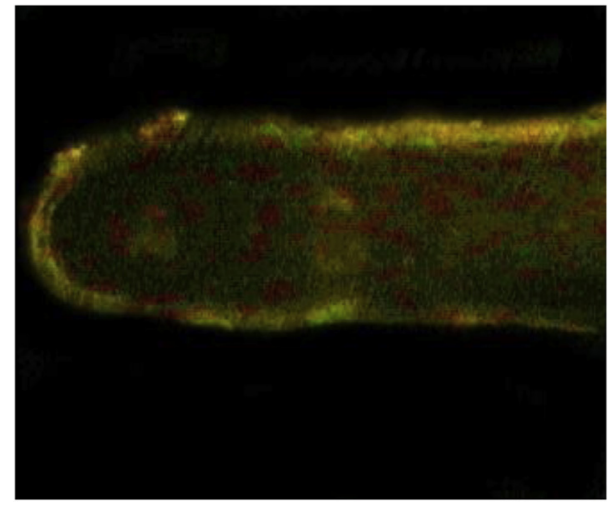

Fig. 12. Histochemistry of polyphenolic compounds in the healthy leaf.

presence of hypertrofied esquizogenic canals and epidermis in $B$. dracunculifolia; galls observed in B. spicata do not have schizogenic canals and its epidermis has an hypodermis below them. Despite these differences and given the fact that they share the same morphotype, patterns of cell elongation would be similar between both galls. Cell hyperplasia and hypertrophy are also common features in both interactions. Same as with the structures here presented, the inner surface of $B$. dracunculifoliae galls also show a great amount of wax deposits.

Based on these results, it could be concluded that psyllidinduced galls in B. spicata are oriented to secure the subsistence of the insect, mainly during its nymphal stages, in xeric conditions and high solar irradiation.

\section{Conclusion}

The results show that the psyllid not only manipulates plant tissues but also induces changes in the biosynthesis of secondary 


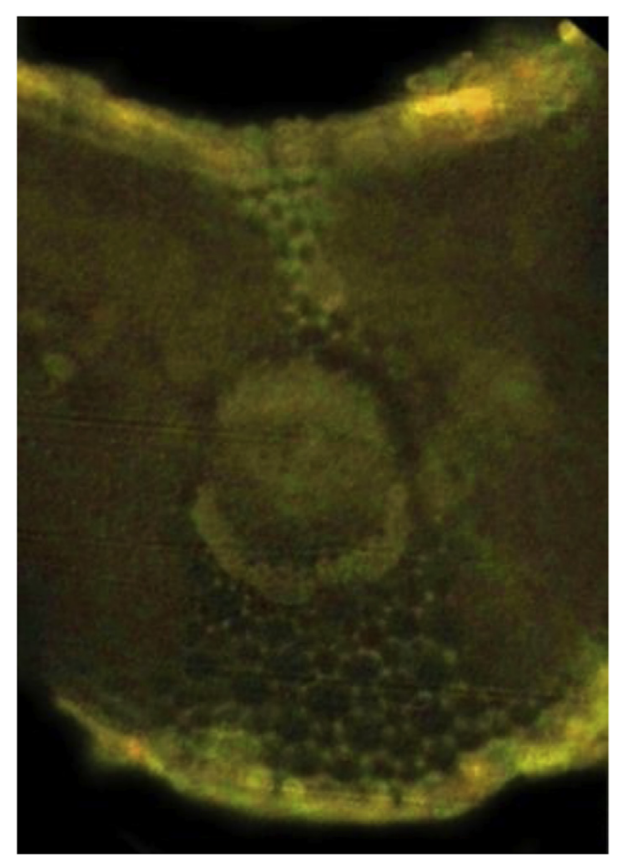

Fig. 13. Histochemistry of the polyphenolic compounds in the vascular bundle.

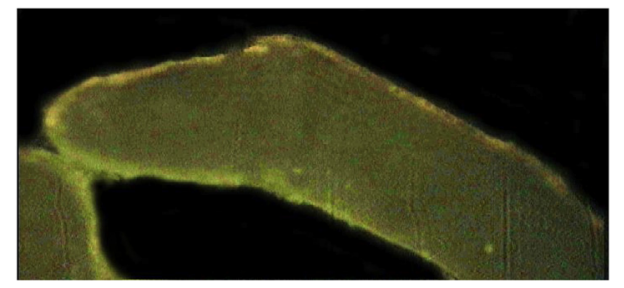

Fig. 14. Histochemistry of the polyphenolic compounds in the gall mesophyll.

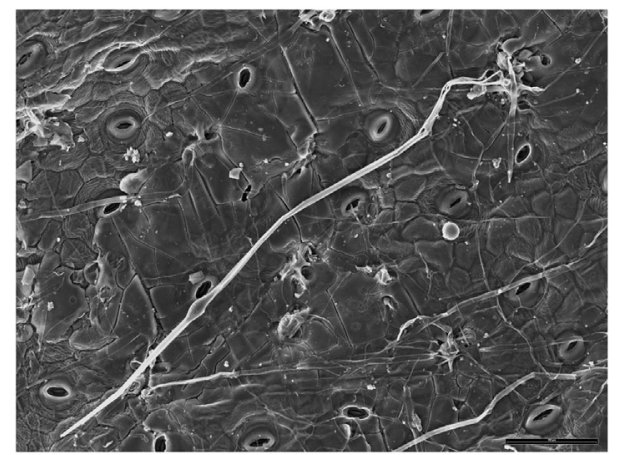

Fig. 15. Epidermis and flagelliform trichoma in healthy leaf.

polyphenolic metabolites that mediate between the gall and its surroundings. The increase in the expression of waxes suggests a protective function against the desiccation by preventing water evaporation in the structure and damage induced by UV radiation. It would be interesting to know the histological features of the emerging gall, in order to elucidate early changes induced by the insect.

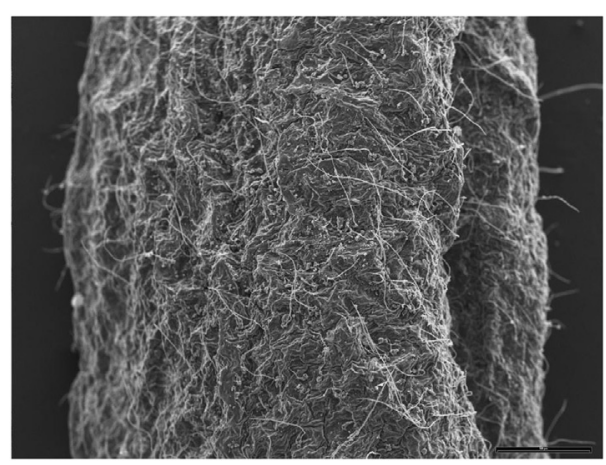

Fig. 16. Scanning electron microscopy of the external face of the gall.

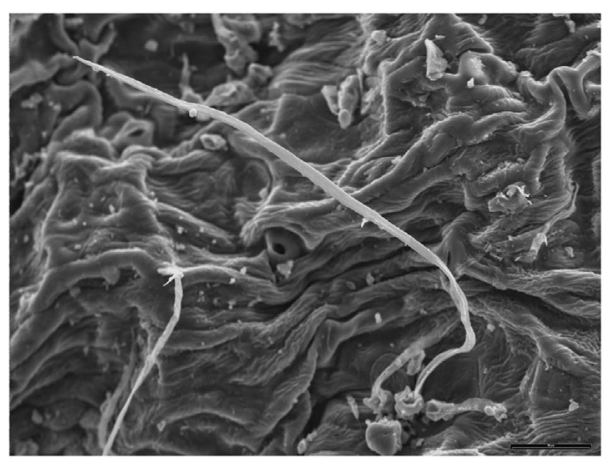

Fig. 17. Scanning electron microscopy of epicuticular wax ridges in the external face of the gall.

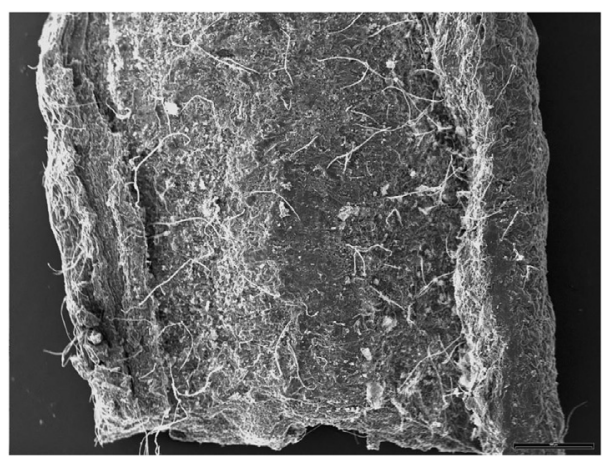

Fig. 18. Scanning electron microscopy of the internal face of the gall.

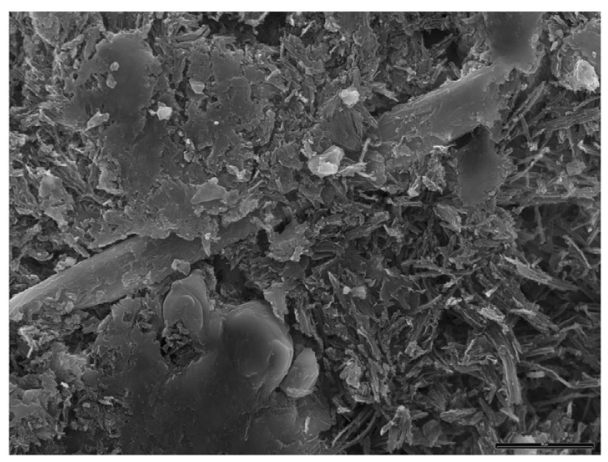

Fig. 19. Scanning electronic microscopy of the broken layers and the cristals of the internal face of the gall. 


\section{Acknowledgments}

The authors wish to thank the two anonymous reviewers for their advice.This work was funded by a grant of the University of Buenos Aires (UBA 20020130100641 BA; Scientific Programming 2014-2017).

\section{References}

Ahn, Y.-J., Lee, H.-S., Oh, H.-S., Kim, H.-T., Lee, Y.-H., 2005. Antifungal activity and mode of action of Galla rhois-derived phenolics against phytopathogenic fungi. Pestic. Biochem. Physiol. 81, 105-112. https://doi.org/10.1016/ j.pestbp.2004.10.003.

Aboy, A.L., Apel, M.A., Debenedetti, S., Francescato, L., Rosella, M.A., Henriques, A.T., 2012. Assay of caffeoylquinic acids in Baccharis trimera by reversed-phase liquid chromatography. J. Chromatogr. A 1219, 147-153. https://doi.org/ 10.1016/j.chroma.2011.11.042.

Agudelo, I.J., Isolabella, S.A., Filip, R., Wagner, M.L., Ricco, R.A., 2016. Baccharis spicata (Lam) Baill: polyphenol screening, determination of their antioxidant activity and their main polyphenolic metabolites. J. Pharmacogn. Phytochem. 5 (6), 278-285.

Agudelo, I.J., Wagner, M.L., Gurni, A.A., Ricco, R.A., 2013. Dinámica de polifenoles y estudio anatomohistoquímico en Schinus longifolius (Lindl.) Speg. (Anacardiaceae) en respuesta a la infección por Calophya mammifex (Hemiptera - calophyidae). Bol. Latinoam. Caribe Plantas Med. Aromat. (BLACPMA) 12 (2), $162-175$.

Arduin, M., Fernandes, G.W., Kraus, J.E., 2005. Morphogenesis of galls induced by Baccharopelma dracunculifoliae (Hemiptera: psyllidae) on Baccharis dracunculifolia (Asteraceae) leaves. Braz. J. Biol. 65, 559-571. https://doi.org/ 10.1590/s1519-69842005000400002.

Argüeso, Ana D'Ambrogio De, 1986. Manual De Tecnicas En Histologia Vegetal. Hemisferio Sur, Buenos Aires.

Barboza, G.E., 2001. Atlas histo-morfologico de plantas de interes medicinal de uso corriente en Argentina. Museo Botanico Cordoba, Cordoba, Argentina.

Barthlott, W., Neinhuis, C., Cutler, D., Ditsch, F., Meusel, I., Theisen, I., Wilhelmi, H., 1998. Classification and terminology of plant epicuticular waxes. Bot. J. Linn. Soc. 126, 237-260. https://doi.org/10.1111/j.1095-8339.1998.tb02529.x.

Bedetti, C.S., Modolo, L.V., Isaias, R.M.D.S., 2014. The role of phenolics in the control of auxin in galls of Piptadenia gonoacantha (Mart.) MacBr (Fabaceae: mimosoideae). Biochem. Systemat. Ecol. 55, 53-59. https://doi.org/10.1016/ j.bse.2014.02.016.

Besten, M.A., Nunes, D.S., Granato, D., Sens Jr., S.L., A.W., Simionatto, E.L., RivaScharf, D., 2014. Volatile components from galls induced Bybaccharopelma dracunculifoliae(Hemiptera: psyllidae) on leaves of baccharis dracunculifolia(Asteraceae). Quím. Nova. https://doi.org/10.5935/0100-4042.20140288.

Burckhardt, 2008. Psylloidea, 2008. In: Claps, L.E., Debandi, G., Roig-Juñent, S. (Eds.), Biodiversidad de Artrópodos Argentinos, vol. 2. Sociedad Entomológica Argentina, Buenos Aires.

Cabrera, A.L., Zardini, E.M., 1978. Manual de la flora de los alrededores de Buenos Aires. Editorial Acme, Buenos Aires.

Carneiro, R., Castro, A., Isaias, R., 2014. Unique histochemical gradients in photosynthesis-deficient plant gall. South Afr. J. Bot. 92, 97-104. https:/ doi.org/10.1016/j.sajb.2014.02.011.

Clifford, M.N., Madala, N.E., 2017. Surrogate standards: a cost-effective strategy for identification of phytochemicals. J. Agric. Food Chem. 65, 3589-3590. https:// doi.org/10.1021/acs.jafc.7b01588.

Cornell, H.V., 1983. The secondary chemistry and complex morphology of galls formed by the cynipinae (hymenoptera): why and how? Am. Midl. Nat. 110, 225. https://doi.org/10.2307/2425263.

Cortadi, A., Sapio, O.D., Cargo, J.M., Scandizzi, A., Gattuso, S., Gattuso, M., 1999 Anatomical studies of Baccharis articulata, Baccharis crispa and Baccharis trimera, "carquejas" used in folk medicine. Pharmaceut. Biol. 37, 357-365. https:/ doi.org/10.1076/phbi.37.5.357.6054.

Fernandes, G.W., Silva, J.O., Espírito-Santo, M.M., Fagundes, M., Oki, Y., Carneiro, M.A.A., 2014. Baccharis: a neotropical model system to study insect plant interactions. Neotropical Insect Galls 193-219. https://doi.org/10.1007 978-94-017-8783-3_13.

Ferreira, B.G., Teixeira, C.T., Isaias, R.M.S., 2014. Efficiency of the polyethylene-glycol (PEG) embedding medium for plant histochemistry. J. Histochem. Cytochem. 62, 577-583. https://doi.org/10.1369/0022155414538265.

Ferreira, B.G., Falcioni, R., Guedes, L.M., Avritzer, S.C., Antunes, W.C., Souza, L.A. Isaias, R.M., 2017. Preventing false negatives for histochemical detection of phenolics and lignins in PEG-embedded plant tissues. J. Histochem. Cytochem. 65, 105-116. https://doi.org/10.1369/0022155416677035.

Filip, R., Ferraro, G.E., 2003. Researching on new species of "Mate": Ilex brevicuspis. Eur. J. Nutr. 42, 50-54. https://doi.org/10.1007/s00394-003-0399-1.

Filip, R., López, P., Giberti, G., Coussio, J., Ferraro, G., 2001. Phenolic compounds in seven South American Ilex species. Fitoterapia 72, 774-778. https://doi.org/ 10.1016/s0367-326x(01)00331-8.

Grecco, S.D.S., Gimenes, L., Ferreira, M.J., Romoff, P., Favero, O.A., Zalewski, C.A., Lago, J.H.G., 2010. Triterpenoids and phenolic derivatives from Baccharis uncinella C.DC. (Asteraceae). Biochem. Systemat. Ecol. 38, 1234-1237. https:// doi.org/10.1016/j.bse.2010.12.005

Halbwirth, H., 2010. The creation and physiological relevance of divergent hydroxylation patterns in the flavonoid pathway. Int. J. Mol. Sci. 11, 595-621. https://doi.org/10.3390/ijms11020595.

Harper, L.J., Schonrogge, K., Lim, K.Y., Francis, P., Lichtenstein, C.P., 2004. Cynipid galls: insect-induced modifications of plant development create novel plant organs. Plant, Cell and Environ. 27, 327-335. https://doi.org/10.1046/j.13653040.2004.01145.x.

Hartley, S.E., Lawton, J.H., 1992. Host-plant manipulation by gall-insects: a test of the nutrition hypothesis. J. Anim. Ecol. 61, 113. https://doi.org/10.2307/5514.

Hartley, S.E., 1998. The chemical composition of plant galls: are levels of nutrients and secondary compounds controlled by the gall-former? Oecologia 113, 492-501. https://doi.org/101007/s004420050401.

Isaias, R.M.D.S., Oliveira, D.C.D., Carneiro, R.G.D.S., Kraus, J.E., 2014a. Developmental anatomy of galls in the neotropics: arthropods stimuli versus host plant constraints. Neotropical Insect Galls 15-34. https://doi.org/10.1007/978-94-0178783-3_2.

Isaias, R.M.D.S., Carneiro, R.G.D.S., Santos, J.C., Oliveira, D.C.D., 2014b. Gall morphotypes in the neotropics and the need to standardize them. Neotropical Insect Galls 51-67. https://doi.org/10.1007/978-94-017-8783-3 4.

Isolabella, S., Cogoi, L., López, P., Anesini, C., Ferraro, G., Filip, R., 2010. Study of the bioactive compounds variation during yerba mate (Ilex paraguariensis) processing. Food Chem. 122, 695-699. https://doi.org/10.1016/ j.foodchem.2010.03.039.

Magalhães, T.A., Oliveira, D.C.D., Suzuki, A.Y.M., Isaias, R.M.D.S., 2013. Patterns of cell elongation in the determination of the final shape in galls of Baccharopelma dracunculifoliae (Psyllidae) on Baccharis dracunculifolia DC (Asteraceae). Protoplasma 251, 747-753. https://doi.org/10.1007/s00709-013-0574-z.

Martino, V.S., Debenedetti, S.L., Coussio, J.D., 1979. Caffeoylquinic acids from Pterocaulon virgatum and Pluchea sagittalis. Phytochemistry 18, 2052. https:// doi.org/10.1016/s0031-9422(00)82742-9.

Mapes, C.C., Davies, P.J., 2001. Indole-3-acetic acid and ball gall development on Solidago altissima. New Phytol. 151, 195-202. https://doi.org/10.1046/j.14698137.2001.00161x.

Marques, V., Farah, A., 2009. Chlorogenic acids and related compounds in medicinal plants and infusions. Food Chem. 113, 1370-1376. https://doi.org/10.1016/ j.foodchem.2008.08.086.

Matsuki, M., 1996. Regulation of plant phenolic synthesis: from biochemistry to ecology and evolution. Aust. J. Bot. 44, 613. https://doi.org/10.1071/bt9960613.

Moglia, A., Lanteri, S., Comino, C., Hill, L., Knevitt, D., Cagliero, C., Rubiolo, P., Bornemann, S., Martin, C., 2014. Dual catalytic activity of hydroxycinnamoylcoenzyme a quinate transferase from tomato allows it to moonlight in the synthesis of both mono- and dicaffeoylquinic acids. Plant Physiol. 166, 1777-1787. https://doi.org/10.1104/pp.114.251371.

Nyman, T., Julkunen-Tiitto, R., 2000. Manipulation of the phenolic chemistry of willows by gall-inducing sawflies. Proc. Natl. Acad. Sci. Unit. States Am. 97, 13184-13187. https://doi.org/10.1073/pnas.230294097.

Nyman, T., Widmer, A., Roininen, H., 2000. Evolution of gall morphology and hostplant relationships in willow-feeding sawflies (hymenoptera: Tenthredinidae). Evolution 54, 526-533. https://doi.org/10.1111/j.0014-3820.2000.tb00055.x.

Oliveira, D., Isaias, R., Fernandes, G., Ferreira, B., Carneiro, R., Fuzaro, L., 2016. Manipulation of host plant cells and tissues by gall-inducing insects and adaptive strategies used by different feeding guilds. J. Insect Physiol. 84, 103-113. https://doi.org/10.1016/j.jinsphys.2015.11.012.

Oliveira, D.C.D., Isaias, R.M.D.S., Moreira, A.S.F.P., Magalhães, T.A., Lemos-Filho, J.P.D. 2011. Is the oxidative stress caused by Aspidosperma spp. galls capable of altering leaf photosynthesis? Plant Sci. 180, 489-495. https://doi.org/10.1016/ j.plantsci.2010.11.005.

Pascual-Alvarado, E., Cuevas-Reyes, P., Quesada, M., Oyama, K., 2008. Interactions between galling insects and leaf-feeding insects: the role of plant phenolic compounds and their possible interference with herbivores. J. Trop. Ecol. 24 329-336. https://doi.org/10.1017/s0266467408005038.

Patankar, R., Thomas, S.C., Smith, S.M., 2011. A gall-inducing arthropod drives declines in canopy tree photosynthesis. Oecologia 167, 701-709. https://doi.org/ 10.1007/s00442-011-2019-8.

Quideau, S., Deffieux, D., Douat-Casassus, C., Pouysegu, L., 2011. ChemInform abstract: plant polyphenols: chemical properties, biological activities, and synthesis. ChemInform 42. https://doi.org/10.1002/chin.201117261.

Raman, A., 2011. Morphogenesis of insect-induced plant galls: facts and questions. Flora - Morphol. Distrib. Funct. Ecol. Plants 206, 517-533. https://doi.org/ 10.1016/j.flora.2010.08.004.

Ricco, R.A., Agudelo, I.J., Wagner, M.L., 2015. Métodos empleados en el análisis de los polifenoles en un laboratorio de baja complejidad. Lilloa 52 (2), 161-174, 2015.

Ryan, K.G., Swinny, E.E., Markham, K.R., Winefield, C., 2002. Flavonoid gene expression and UV photoprotection in transgenic and mutant Petunia leaves. Phytochemistry 59, 23-32. https://doi.org/10.1016/s0031-9422(01)00404-6.

Simões-Pires, C.A., Queiroz, E.F., Henriques, A.T., Hostettmann, K., 2005. Isolation and on-line identification of anti-oxidant compounds from three Baccharis species by HPLC-UV-MS/MS with post-column derivatisation. Phytochem. Anal. 16, 307-314. https://doi.org/10.1002/pca.826.

Shorthouse, J.D., 1992. Biology of Insect Induced Galls. Oxford Univ. Press, New York.

Shorthouse, J.D., Wool, D., Raman, A., 2005. Gall-inducing insects - nature's most sophisticated herbivores. Basic Appl. Ecol. 6, 407-411. https://doi.org/10.1016/ j.baae.2005.07.001.

Simmonds, M.S., 2003. Flavonoid-insect interactions: recent advances in our 
knowledge. Phytochemistry 64, 21-30. https://doi.org/10.1016/s0031-9422(03) 00293-0.

Simmonds, M.S., 2001. Importance of flavonoids in insect-plant interactions: feeding and oviposition. Phytochemistry 56, 245-252. https://doi.org/10.1016/ s0031-9422(00)00453-2.

Stone, G.N., Schönrogge, K., 2003. The adaptive significance of insect gall morphology. Trends Ecol. Evol. 18, 512-522. https://doi.org/10.1016/s01695347(03)00247-7.

Stone, G.N., Cook, J.M., 1998. The structure of cynipid oak galls: patterns in the evolution of an extended phenotype. Proc. Biol. Sci. 265, 979-988. https:// doi.org/10.1098/rspb.1998.0387.
Taper, M.L., Case, T.J., 1987. Interactions between oak tannins and parasite community structure: unexpected benefits of tannins to cynipid gall-wasps Oecologia 71, 254-261. https://doi.org/10.1007/bf00377292.

Tooker, J.F., Rohr, J.R., Abrahamson, W.G., Moraes, C.M.D., 2008. Gall insects can avoid and alter indirect plant defenses. New Phytol. 178, 657-671. https:// doi.org/10.1111/j.1469-8137.2008.02392.x.

Waterman, P.G., Mole, S., 1994. Analysis of Phenolic Plant Metabolites. Blackwell Scientific, Oxford.

Yeats, T.H., Rose, J.K.C., 2013. The Formation and function of plant cuticles. Plant Physiol. 163, 5-20. https://doi.org/10.1104/pp.113.222737. 